\title{
HUMAN TOXOCARIASIS: FREQUENCY OF ANTI-TOXOcara ANTIBODIES IN CHILDREN AND ADOLESCENTS FROM AN OUTPATIENT CLINIC FOR LYMPHATIC FILARIASIS IN RECIFE, NORTHEAST BRAZIL
}

Ana Maria AgUiAR-SANTOS(1), Luiz D. ANDRADE(1), Zulma MEDEIROS(2), Pedro Paulo CHIEFFI(3), Suzana Z. LESCANO(3) \& Emília P. PEREZ(1)

\begin{abstract}
SUMMARY
In a transversal study on a sample of 386 children and adolescents from an outpatient clinic for filariasis in Recife, Northeast Brazil, the frequency of anti-Toxocara antibodies and its relation to age, gender, number of peripheral eosinophils, Wuchereria bancrofti microfilariae and intestinal helminths was determined. The total anti-Toxocara IgG antibody frequency was $39.4 \%$, by ELISA technique. The difference in frequency between males (40.1\%) and females (37.6\%) was not statistically significant. The 6 to 10 -year-old subset presented the highest frequency of anti-Toxocara antibodies (60\%), and within this age group there was a statistically significant male bias. There was also a significant association between the number of eosinophils and the presence of anti-Toxocara antibodies. Intestinal parasite frequency was $52.1 \%$, but no association was found between this data and the presence of anti-Toxocara antibodies. In the present sample, $42.2 \%$ of the patients were Wuchereria bancrofti carriers, however, again this was not associated with the presence of anti-Toxocara antibodies. In conclusion, anti-Toxocara antibodies were highly prevalent in this sample. The present data show that there is no cross correlation between anti-Toxocara IgG antibody and the presence of intestinal helminths and filariasis.
\end{abstract}

KEYWORDS: Toxocariasis; Visceral larva migrans; Anti-Toxocara antibodies; Toxocara canis; Eosinophilia; Wuchereria bancrofti.

\section{INTRODUCTION}

BEAVER et al. (1952) described Visceral Larva Migrans syndrome (VLMS) as a prolonged migration of helminth larvae in the organism of unusual hosts. Toxocara canis is the agent most commonly implicated in the etiology of this illness among human populations ${ }^{3}$. Infection originates from soil contaminated with parasite eggs eliminated in the feces of common host species, such as dogs and cats. In humans, the parasite completes a somatic-pulmonary biological cycle, which may manifest itself in one of three clinical forms ${ }^{13}$ : VLMS (originating from the larval invasion of human tissues); ocular toxocariasis (specific signs and symptoms at the ocular globe); and asymptomatic toxocariasis.

Toxocariasis diagnosis used to be based on clinical data or the occasional finding of larvae within tissues. An important improvement occurred with the development of Enzyme Linked Immunosorbent Assay (ELISA) using Toxocara canis excretion-secretion antigens that allowed broader epidemiological studies to be carried out. It has been found that the parasitic infection prevalence varies widely in the globe and even within a single country, due to its epidemiological characteristics ${ }^{4,14,18,21,24,25,31}$.

In many Brazilian regions, particularly in the Northeast countryside, one should expect to find a higher prevalence than those presently reported in the U.S. or Europe. Despite the favorable epidemiological conditions for mass occurrence of human infection, such as the large number of $T$. canis infected street $\operatorname{dog} s^{20}$, there is a surprisingly low frequency of VLMS cases diagnosed in the Brazilian Northeast. However, few epidemiological studies have been carried out on this subject, thus preventing an accurate estimation of the prevalence of toxocariasis for the region. Consequently, these conditions may signify one of the largest unrecognized parasitic infections in Recife and in view of the potential morbidity further investigation is warranted.

The present study was done in order to determine the frequency of anti-Toxocara antibodies in the serum of children and adolescents exposed to other endemic parasitosis in Recife, as well as to verify the possible role of these infections on the anti-Toxocara serology.

\section{MATERIAL AND METHODS}

A transversal study was carried out on children and adolescents attended at Centro de Pesquisas Aggeu Magalhães (CPqAM/Fiocruz) outpatient clinic, a national reference center for lymphatic filariasis, in Recife city (Brazilian Northeast) from 1987 to 1996.

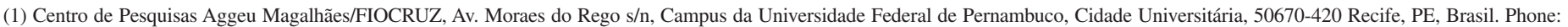
(81) 33012573; fax: (81) 3453 2449. E-mail: amas@cpqam.fiocruz.br

(2) Centro de Pesquisas Aggeu Magalhães/FIOCRUZ, Instituto de Ciências Biológicas/UPE.

(3) Instituto de Medicina Tropical de São Paulo/USP, Av. Dr. Enéas de Carvalho Aguiar 470, 05403-000 S. Paulo, SP, Brasil.

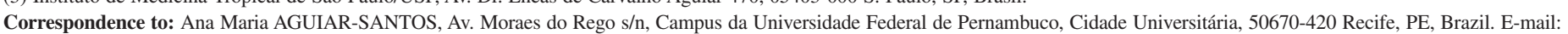
amas@cpqam.fiocruz.br 


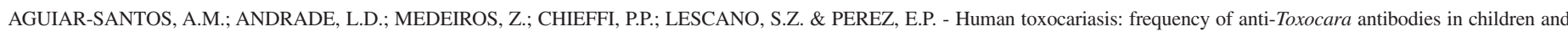
adolescents from an outpatient clinic for lymphatic filariasis in Recife, northeast Brazil. Rev. Inst. Med. trop. S. Paulo, 46(2):81-85, 2004.

The sample studied consisted of 500 individuals, all less than 19 years old. Taking into account an $11 \%$ expected prevalence and $95 \%$ confidence interval, a minimum of 326 individuals was estimated. In fact, a total of 386 patients were selected and examined, of which 269 were male (69.7\%) and $117(30.3 \%)$ were female. Individuals without serological samples available were excluded.

The following routine laboratory exams were performed: sera antiToxocara antibodies; eosinophils absolute count and tests for intestinal parasites and Wuchereria bancrofti microfilariae in the blood sample.

Eosinophils absolute count was obtained by direct inspection in a Neubauer chamber ${ }^{27}$, with a reference value ${ }^{7}$ of 500 eosinophils $/ \mathrm{mm}^{3}$. For larvae, eggs and cysts study of the intestinal parasites, the Lutz method as well as the Baerman-Moraes method were applied, using one or more stool samples for diagnosis. Protozoan species were not identified.

Membrane filtration technique was used in filariasis study, as described by DENNIS \& KEAN ${ }^{10}$. Venous blood samples were collected between 11:00 p.m. and 1:00 a.m., according to the circadian periodicity of microfilariae ${ }^{11}$.

Total IgG anti-Toxocara antibodies study was carried out by ELISA immuno-enzymatic method, using secretory and excretory antigens from second stage larvae $\left(\mathrm{L}_{2}\right)$ cultivated in vitro ${ }^{8,9}$. All sera were adsorbed with total Ascaris suum antigenic extract to avoid cross reactions between Toxocara antigens and Ascaris antibodies ${ }^{1,22}$. The cutoff density point in serological assays varied from 0.520 to 0.720 and was determined for every test using the mean of the negative controls plus two standard deviations (2 SD).

EPi Info 6.04 software was used for statistical analysis. A descriptive univariate analysis was carried out to verify the frequency of the variables and the seroprevalence of anti-Toxocara antibodies in the total sample, pooled according to gender and age. The relative proportions were calculated with a confidence interval of $95 \%$. To identify possible associations between dependent variable (seropositivity for Toxocara) and independent variables Pearson chi-square test with Yates correction was used. The significance level was set at $5 \%$.

The protocol design as well as the use of biological fluid samples stocked at our Institution had the approval of the local ethical committee.

\section{RESULTS}

General characterization of population study: Eosinophil count was carried out on $303(78.5 \%)$ of the 386 individuals enrolled. Of these, $67.7 \%$ were eosinophilic (values above 500 eosinophils $/ \mathrm{mm}^{3}$ ), whereas $35.9 \%$ presented hypereosinophilia, i.e. values above 1000 eosinophils/ $\mathrm{mm}^{3}$.

Intestinal helminths were present in $52.1 \%$ of individuals that underwent coprological examination. Table 1 describes the intestinal parasites found and summarizes the frequency, as well as other characteristics of the sample population.

Wuchereria bancrofti microfilariae (mf) study was carried out on
Table 1

Distribution according to age, gender, number of peripheral eosinophils, presence of intestinal parasites and Wuchereria bancrofti microfilariae in children and adolescents from an outpatient clinic in Recife, Northeast Brazil

\begin{tabular}{|c|c|c|c|}
\hline Variables & $\mathrm{N}$ & $\%$ & CI $95 \%$ \\
\hline Age (years) & 386 & 100 & \\
\hline$\leq 5$ & 28 & 7.2 & $4.9-10.3$ \\
\hline $6-10$ & 45 & 11.7 & 8.6-15.3 \\
\hline $11-15$ & 110 & 28.5 & $24.0-33.3$ \\
\hline $16-18$ & 203 & 52.6 & $47.5-57.7$ \\
\hline Sex & 386 & 100 & \\
\hline Male & 269 & 69.7 & $64.8-74.2$ \\
\hline Female & 117 & 30.3 & $25.8-35.2$ \\
\hline Eosinophils $\left(\mathrm{mm}^{3}\right)^{1}$ & 303 & 100 & \\
\hline$\leq 500$ & 98 & 32.3 & 27.1-37.9 \\
\hline $501-1000$ & 96 & 31.7 & $26.5-37.2$ \\
\hline $1001-3000$ & 78 & 25.7 & $20.9-31.0$ \\
\hline$>3000$ & 31 & 10.2 & 7.1-14.2 \\
\hline Wuchereria bancrofti ${ }^{2}$ & 353 & 100 & \\
\hline Positive & 149 & 42.2 & $37.0-47.5$ \\
\hline Negative & 204 & 57.8 & $52.4-63.0$ \\
\hline Intestinal parasites ${ }^{3}$ & 382 & 100 & \\
\hline Total negative & 183 & 47.9 & $42.8-53.0$ \\
\hline Total positive ${ }^{4}$ & 199 & 52.1 & $46.9-57.2$ \\
\hline Strongyloides stercoralis & 30 & 7.9 & 5.4-11.0 \\
\hline Ascaris lumbricoides & 102 & 26.7 & 22.3-31.4 \\
\hline Ancylostomatidae & 50 & 13.1 & $9.9-16.9$ \\
\hline Trichuris trichiura & 105 & 27.5 & $23.1-32.3$ \\
\hline Schistosoma mansoni & 13 & 3.4 & $1.8-5.7$ \\
\hline Enterobius vermicularis & 4 & 1.0 & $0.3-2.7$ \\
\hline Taenia sp. & 4 & 1.0 & $0.3-2.7$ \\
\hline Protozoa & 78 & 20.4 & $16.5-24.8$ \\
\hline
\end{tabular}

${ }^{1}$ Lack of information from 83 individuals $(21.5 \%) ;{ }^{2}$ Lack of information from 33 individuals $(8.5 \%) ;{ }^{3}$ Lack of information from 04 individuals $(1.0 \%) ;{ }^{4}$ Some individuals were polyparasitic.

353 individuals (91.4\% of overall sample), and $42.2 \%$ were diagnosed as carriers. The mean density was $410 \mathrm{mf} / \mathrm{ml}$ (range 1 to $12.650 \mathrm{mf} / \mathrm{ml}$ ).

Frequency of anti-Toxocara antibodies in relation to gender, age, the presence of intestinal parasites or $W$. bancrofti microfilariae: AntiToxocara antibodies frequency was $39.4 \%$ (152/386). The antibody frequency among male individuals was $40.1 \%$ (108/269) while in females it was $37.6 \%(44 / 117)$. This difference was not statistically significant (Table 2). However, when a stratified analysis by age group was carried out, a $88.9 \%$ antibodies frequency was found in males aged 6 to 10 , compared to $40.7 \%$ in age paired females. Thus, there was a statistically significant greater risk (2.1 times) of being seropositive for males in this age group.

The highest seropositivity frequency was found in the 6 to 10-yearold subgroup, representing $60 \%$ (27/45) of positive individuals. This was followed by individuals aged 11 to 15 years; less than or equal to 5 years; and 16 to 18 years with $46.4 \%$ (51/110), 32.1\% (9/28) and 32\% $(65 / 203)$ seropositivity, respectively. All of these subgroups presented statistically significant differences (Table 2). 


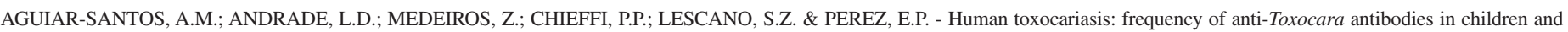
adolescents from an outpatient clinic for lymphatic filariasis in Recife, northeast Brazil. Rev. Inst. Med. trop. S. Paulo, 46(2):81-85, 2004.

Table 2

Distribution of serology for Toxocara according to gender, age, Wuchereria bancrofti microfilariae, number of peripheral eosinophils, and intestinal parasitic infection in children and adolescents from an out-patient clinic in Recife, Northeast Brazil

\begin{tabular}{|c|c|c|c|c|c|c|c|c|}
\hline \multirow{3}{*}{ Variables } & \multicolumn{6}{|c|}{ Serology for Toxocara } & \multirow{3}{*}{\multicolumn{2}{|c|}{ Statistics }} \\
\hline & \multicolumn{2}{|c|}{ Positive } & \multicolumn{2}{|c|}{ Negative } & \multicolumn{2}{|c|}{ Total } & & \\
\hline & $\mathrm{N}$ & $\%$ & $\mathrm{~N}$ & $\%$ & $\mathrm{~N}$ & $\%$ & & \\
\hline \multicolumn{9}{|l|}{ Sex } \\
\hline Male & 108 & 40.1 & 161 & 59.9 & 269 & 100.0 & $64.8-74.2$ & $\chi^{2}=0.13(\mathrm{Y})$ \\
\hline Female & 44 & 37.6 & 73 & 62.4 & 117 & 100.0 & $25.8-35.2$ & $p=0.72$ \\
\hline Total & 152 & 39.4 & 234 & 60.6 & 386 & 100.0 & & \\
\hline \multicolumn{9}{|l|}{ Age group } \\
\hline$\leq 5$ years & 9 & 32.1 & 19 & 67.9 & 28 & 100.0 & $4.9-10.3$ & \\
\hline $6-10$ years & 27 & 60.0 & 18 & 40.0 & 45 & 100.0 & $8.6-15.3$ & $\chi^{2}=15.48(\mathrm{Y})$ \\
\hline $11-15$ years & 51 & 46.4 & 59 & 53.6 & 110 & 100.0 & $24.0-33.3$ & $\mathrm{p}=0.001$ \\
\hline $16-18$ years & 65 & 32.0 & 138 & 68.0 & 203 & 100.0 & $47.5-57.7$ & \\
\hline Total & 152 & 39.4 & 234 & 60.6 & 386 & 100.0 & & \\
\hline \multicolumn{9}{|c|}{ Wuchereria bancrofti } \\
\hline Positive & 67 & 45.0 & 82 & 55.0 & 149 & 100.0 & $37.0-47.6$ & $\chi^{2}=2.08(\mathrm{Y})$ \\
\hline Negative & 75 & 36.8 & 129 & 63.2 & 204 & 100.0 & $52.5-63.0$ & $p=0.15$ \\
\hline Total & 142 & 40.2 & 211 & 59.8 & 353 & 100.0 & & \\
\hline \multicolumn{9}{|c|}{ Number of eosinophils } \\
\hline$\leq 500$ & 14 & 14.3 & 84 & 85.7 & 98 & 100.0 & 27.1-37.9 & \\
\hline $501-1000$ & 40 & 41.7 & 56 & 58.3 & 96 & 100.0 & $26.5-37.2$ & $\chi^{2}=41.99(\mathrm{Y})$ \\
\hline $1001-3000$ & 44 & 56.4 & 34 & 43.6 & 78 & 100.0 & $20.9-31.0$ & $\mathrm{p}<0.001$ \\
\hline$>3000$ & 19 & 61.3 & 12 & 38.7 & 31 & 100.0 & $7.1-14.2$ & \\
\hline Total & 117 & 38.6 & 186 & 61.4 & 303 & 100.0 & & \\
\hline \multicolumn{9}{|l|}{ Parasite infection } \\
\hline Positive & 77 & 38.7 & 122 & 61.3 & 199 & 100.0 & $47.0-57.2$ & $\chi^{2}=0.00(Y)$ \\
\hline Negative & 72 & 39.3 & 111 & 60.7 & 183 & 100.0 & $42.8-53.0$ & $\mathrm{p}=0.98$ \\
\hline Total & 149 & 39.0 & 233 & 61.0 & 382 & 100.0 & & \\
\hline
\end{tabular}

Considering only those individuals with positive serology that also underwent studies for Wuchereria bancrofti, 52.8\% (75/142) were not carriers while $47.2 \%(67 / 142)$ were carriers. This difference was not statistically significant.

Around $51.7 \%$ of seropositive children and adolescents presented some type of intestinal parasite whereas no parasite was detected in 48.3\%. This difference was not statistically significant.

In relation to seropositive individuals with an eosinophil count, $12 \%$ (14/117) presented normal eosinophil values, whereas 53.8\% (63/117) had hypereosinophilia. Individuals with higher eosinophil counts $(>3000$ cells $/ \mathrm{mm}^{3}$ ) also presented a greater frequency of anti-Toxocara antibodies $(61.3 \%)$ (Fig. 1). Only 35 individuals had hypereosinophilia without associated intestinal parasitosis or filariasis and among these, 16 presented anti-Toxocara antibodies.

The relation between the number of eosinophils and seropositivity frequencies was statistically significant, with a 4.29 times greater seropositivity risk in individuals with values above 3000 eosinophils $/ \mathrm{mm}^{3}$ when compared to those with less than or equal to 500 eosinophils $/ \mathrm{mm}^{3}$ (Fig. 1).

\section{DISCUSSION}

We are aware that the anti-Toxocara antibodies frequency in the

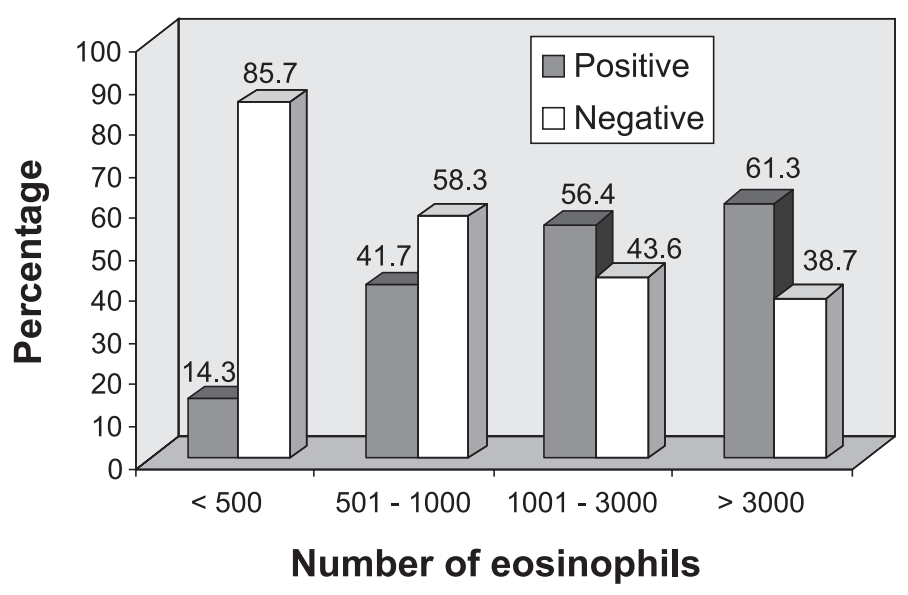

Fig. 1 - Frequency of positive and negative serology for Toxocara in children and adolescents at an outpatient clinic in Recife, Northeast Brazil, according to the number of eosinophils

current study may not reflect its real prevalence in the population of the Recife metropolitan region. Nevertheless, the present data are relevant as can figure out the Toxocara prevalence in a population sample exposed to other intestinal parasitosis, especially Wuchereria bancrofti.

Our Institution's outpatient clinic attends a large number of individuals with peripheral eosinophilia. This eventual laboratory finding 


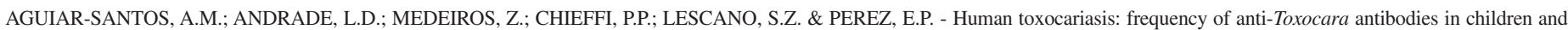
adolescents from an outpatient clinic for lymphatic filariasis in Recife, northeast Brazil. Rev. Inst. Med. trop. S. Paulo, 46(2):81-85, 2004.

is the major reason for referral to our ambulatory and leads to a higher overall hypereosinophilic patient profile in relation to the general population. Since the presence of peripheral eosinophilia is one of the laboratorial criteria considered for a presumed Toxocara infection, it should be stated that the present sample population had a greater chance of presenting anti-Toxocara antibodies.

The high frequency of anti-Toxocara antibodies found in this study was similar to reports in Brazil ${ }^{23,26,33}$ and other countries ${ }^{17,21}$ but nevertheless higher than that described by some authors ${ }^{4,14,24,25}$. However, the comparison between the present results and these reports is difficult due to several factors, such as: seroepidemiological studies based on a small number of children; heterogeneity of individuals studied (i.e. blood donors, hospitalized patients or high risk subgroups for toxocariasis); non-standardized laboratory procedures; and different cutoff points in the various serodiagnostic techniques.

Intestinal parasite infection was detected in a high percentage of individuals, resulting in a significant frequency of geohelminths between the detected parasites. They are well known agents for the onset of peripheral eosinophilia ${ }^{28}$. The high frequency of intestinal helminths observed in the present study suggests that other risk factors described for Toxocara infection ${ }^{14,21,31}$, such as poor hygiene habits and inadequate sanitation, must have contributed ${ }^{14,21,31}$.

The frequency analysis of anti-Toxocara antibodies in a population survey from a tropical area with serious sanitary and socioeconomic deficiency is further complicated by potential cross reactivity between a large variety of other parasites to which a given individual may have been exposed. This could lead to false-positive results ${ }^{21}$.

Recife city is considered to be an endemic area of bancroftian filariasis ${ }^{34}$. Thus, the microfilariae examination of serum samples could be important to determine whether a cross reactivity of Toxocara with other nematodes is present in individuals with positive serology. However, present data discarded a correlation between the presence of $W$. bancrofti microfilariae and anti-Toxocara antibodies.

No significant difference was observed between the frequency of intestinal parasites and anti-Toxocara antibodies. Thus, one should be aware of the possibility that these infections overlap in the population.

We found a significant gender difference in antibody frequency only in 6 to 10-year-old subgroup, with a male bias. Our data corroborates other reports that indicate greater frequency of Toxocara infection among males in certain age groups $\mathrm{s}^{9,12,16,19,29}$. Taking into account the Brazilian culture, this difference may be due to more restricted outdoor activities for female children.

The peak antibody frequency found in the present study (6 to 10year-old subgroup) was similar to that described by CHIEFFI et al. in a population study in Santos city, São Paulo State, in southeastern Brazil ${ }^{6}$. They reported a $13.1 \%$ seroprevalence in individuals less than 15 years of age, but the prevalence among those in the 5 to 10 -year-old group reached $19.0 \%$.

A high frequency of anti-Toxocara antibodies among pediatric patients seems to be unquestionable ${ }^{9,16,35}$, but there has been a growing number of reports indicating the presence of infection in adults ${ }^{14,30}$. This is especially relevant to regions considered to be endemic areas for toxocariasis (even for adults), such as the southeast of France ${ }^{15}$. Therefore, while 2 to 5 -year-old children have always been considered the classic age group for susceptibility to VLMS, one should not make the error of considering that toxocariasis is an exclusively childhood illness.

BEAVER $^{2}$ reported a close relation between eosinophilia and visceral larva migrans. Prior to the development of ELISA technique, this criterion for eosinophilia (with mainly extreme values) was adopted as an important laboratorial indicator of toxocariasis. Even today, it is considered a classic criterion of visceral larva migrans. However, the absence of an elevated number of peripheral eosinophils does not exclude the possibility of toxocariasis $^{30}$.

The literature also indicates that eosinophilia in Toxocara seropositive individuals seems to be age related, as it is more common in children than in adults ${ }^{32}$.

Analyzing the present data, we were able to identify other probable causes for eosinophilia besides a possible Toxocara infection, such as the presence of intestinal parasites and filarial infection. The latter appears to be particularly probable in patients with the clinical form of Tropical Pulmonary Eosinophilia (TPE), with elevated values of peripheral eosinophils.

The initial objective of this work was to use anti-Toxocara antibody ELISA to asses the toxocariasis infection at an outpatient clinic in Recife, a recognized endemic area of filariasis and geohelminthiasis. Although the present data does not allow a more profound analysis of all risk factors for Toxocara infection, it strongly suggests that the Brazilian Northeast has a high human toxocariasis prevalence, which has so far been underestimated and, consequently, under-diagnosed. On the other hand, in the present population sample the presence of filariasis apparently does not alter the ELISA test with secretion and excretion L2 antigen, which strengthens the relevance of this nosology within the region.

\section{RESUMO}

\section{Toxocaríase humana: freqüência de anticorpos anti-Toxocara em crianças e adolescentes atendidos em um ambulatório especializado de filariose linfática em Recife, Nordeste do Brasil}

Através de estudo do tipo transversal com amostra constituída por 386 crianças e adolescentes atendidos em um ambulatório especializado de filariose, do Recife, nordeste do Brasil, determinou-se a frequência de anticorpos anti-Toxocara e sua relação com faixa etária, sexo, número de eosinófilos periféricos, microfilárias de Wuchereria bancrofti e parasitos intestinais. A frequiência encontrada de anticorpos IgG total anti-Toxocara, realizada através da técnica de ELISA, foi de $39,4 \%$, com $40,1 \%$ no sexo masculino e 37,6\% no feminino, diferença esta sem significância estatística. O grupo com maior freqüência de anticorpos anti-Toxocara foi o de 6-10 anos $(60 \%)$ e, apenas nessa faixa etária, encontrou-se uma diferença estatisticamente significante quanto ao sexo, com predomínio do masculino. Observou-se associação estatisticamente significante entre o número de eosinófilos e a presença de anticorpos anti-Toxocara. A frequiência de parasitos intestinais foi de $52,1 \%$, porém sem associação entre este achado e a presença de anticorpos anti-Toxocara. Na presente análise, 42,2\% dos 


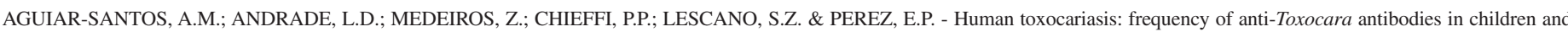
adolescents from an outpatient clinic for lymphatic filariasis in Recife, northeast Brazil. Rev. Inst. Med. trop. S. Paulo, 46(2):81-85, 2004.

pacientes eram portadores de microfilárias de Wuchereria bancrofti, porém esta infecção não esteve associada à presença de anticorpos anti-Toxocara o que sugere que não houve cruzamento do ELISA com a presença de parasitoses intestinais e filariose.

\section{ACKNOWLEDGEMENTS}

The authors are indebted to Prof. André Freire Furtado and Dr. Luiz Bezerra de Carvalho for their valuable suggestions.

\section{REFERENCES}

1.BACH-RIZZATI, B.C. - Desenvolvimento de teste imunoenzimático, ELISA, para o diagnóstico da toxocaríase humana. São Paulo, 1984. (Dissertação de Mestrado Faculdade de Ciências Farmacêuticas da Universidade de São Paulo).

2. BEAVER, P.C. - Toxocarosis (Visceral larva migrans) in relation to tropical eosinophilia. Bull. Soc. Path. exot., 55: 555-576, 1962.

3. BEAVER, P.C.; SNYDER, C.H.; CARRERA, G.M.; DENT, J.H. \& LAFFERTY, J.W. Chronic eosinophilia due to visceral larva migrans. Report of three cases. Pediatrics, 9: 7-19, 1952.

4. BUIJS, J.; BORSBOOM, G.; van GEMUND, J.J. et al. - Toxocara seroprevalence in 5year-old elementary schoolchildren: relation with allergic asthma. Amer. J. Epidem., 140: 839-847, 1994.

5. CHIEFFI, P.P. - Contribuição ao estudo da síndrome de "Larva Migrans" Visceral causada por larvas de Toxocara (STILES \& HASSAL, 1905), em cinco municípios do Estado de São Paulo, Brasil. Inquérito soroepidemiológico, São Paulo, 1984. (Tese de Doutorado - Instituto de Ciências Biomédicas da Universidade de São Paulo).

6. CHIEFFI, P.P.; UEDA, M.; CAMARGO, E.D. et. al. - Visceral larva migrans: a seroepidemiological survey in five municipalities of São Paulo State, Brazil. Rev. Inst. Med. trop. S. Paulo, 32: 204-210, 1990.

7. COGAN, E. - Hyperéosinophilies: mise au point clinique. Hypereosinophilia: a clinical approach. Rev. méd. Bruxelles, 15: 55-60, 1994.

8. De SAVIGNY, D.H. \& TIZARD, I.R. - Serodiagnosis of Toxocara larva migrans visceral. Canad. J. publ. Hlth., 66: 52-56, 1975.

9. De SAVIGNY, D.H; VOLLER, A. \& WOODRUFF, A.W. - Toxocariasis: serological diagnosis by enzyme immunoassay. J. clin. Path., 32: 284-288, 1979.

10. DENNIS, D.T. \& KEAN, B.H. - Isolation of microfilariae: report of a new method. J. Parasit., 57: 1146-1147, 1971.

11. DREYER, G.; PIMENTEL, A; MEDEIROS, Z. et al. - Studies on the periodicity and intravascular distribution of Wuchereria bancrofti microfilariae in paired samples of capillary and venous blood from Recife, Brazil. Trop. Med. Int. Hlth., 1: 264-272, 1996

12. EHRHARD, T. \& KERBAUM, S. - Toxocara canis et toxocarose humaine. Bull. Inst. Pasteur, 77: 225-287, 1979.

13. FENOY, S.; CUELLAR, C. \& GUILLEN, J.L. - Seroprevalence of toxocariasis in children and adults in Madrid and Tenerife, Spain. J. Helminth., 70: 109-113, 1996.

14. GENCHI, C.; Di SACCO, B.; GATTI, S.; SANGALLI, G. \& SCAGLIA, M. -Epidemiology of human toxocariasis in northern Italy. Parassitologia, 32: 313-319, 1990.

15. GLICKMAN, L.T.; MAGNAVAL, J.F.; DOMANSKI, L.M. et al. - Visceral larva migrans in French adults: a new disease syndrome? Amer. J. Epidem., 125: 1019-1034, 1987.

16. GLICKMAN, L.T. \& SCHANTZ, P.M. - Epidemiology and pathogenesis of zoonotic toxocariasis. Epidem. Rev., 3: 230-250, 1981.
17. GUEGLIO, B.; GENTILE, L.; NGUYEN, J.M. et al. - Epidemiology approach to human toxocariasis in western France. Parasit. Res., 80: 531-536, 1994

18. HERRMANN, N.; GLICKMAN, L.T.; SCHANTZ, P.M.; WESTON, M.G. \& DOMANSKI, L.M. - Seroprevalence of zoonotic toxocariasis in the United States: 1971-1973. Amer. J. Epidem., 122: 890-896, 1985

19. HUNTLEY, C.C.; COSTAS, M.C. \& LYERLY, A. - Visceral larva migrans syndrome: clinical characteristics and immunologic studies in 51 patients. Pediatrics, 36: 523 536, 1965.

20. LIMA, J.L.; CARNAVAL, J.O.; SAMICO, C.L.Q.; ANDRADE, L.D. \& AGUIARSANTOS, A.M. - Infecção por toxocarídeos em cães apreendidos em vias públicas, na região metropolitana do Recife-PE, Brasil. In: Bienal de Pesquisa da Fundação Oswaldo Cruz, 2., Rio de Janeiro, 2000. Anais. p. 65.

21. LYNCH, N.R.; EDDY, K.; HODGEN, A.N.; LOPEZ, R.I. \& TURNER, K.J. Seroprevalence of Toxocara canis infection in Tropical Venezuela. Trans. roy. Soc. trop. Med. Hyg., 82: 275-281, 1988.

22. LYNCH, N.R.; WILKES, L.K.; HODGEN, A.N. \& TURNER, K.J. - Specificity of Toxocara ELISA in tropical populations. Paras. Immunol., 10: 323-337, 1988.

23. MATOS, M.F.C.; MILITÃO, D.N.A.; BRUM, M.A.R. et al. - Presence of anti-Toxocara antibodies in children selected at Hospital Universitario, Campo Grande, MS, Brazil. Rev. Inst. Med. trop. S. Paulo, 39: 49-50, 1997.

24. MATSUMURA, K. \& ENDO, R. - Seroepidemiological study on toxocaral infection in man by enzyme-linked immunosorbent assay. J. Hyg. (Lond.), 90: 61-65, 1983.

25. MINVIELLE, M.C.; TAUS, M.R.; RAFFO, A.; CIARMELA, M.L. \& BASUALDO J.A. - Seroprevalence of toxocariasis in blood donors of Gualeguaychú, Argentina Trans. roy. Soc. trop. Med. Hyg., 94: 373-375, 2000.

26. MOREIRA-SILVA, S.F.; LEÃO, M.E.; MENDONÇA, H.F.S. \& PEREIRA, F.E.L. Prevalence of anti-Toxocara antibodies in a random sample of inpatients at a children's hospital in Vitória, Espírito Santo, Brazil. Rev. Inst. Med. trop. S. Paulo, 40: 259261, 1998.

27. PILOT, M.L. - Use of base on fluids for counting eosinophils: a method for staining eosinophilis. Amer. J. Epidem., 20: 17-21, 1950.

28. ROTHENBERG, M.E. - Eosinophilia. New Engl. J. Med., 338: 1592-1600, 1998.

29. SNYDER, C. - Visceral larva migrans, Ten years' experience. Pediatrics, 28: 85-91, 1961.

30. TAYLOR, M.R.; KEANE, C.T.; O'CONNOR, P.; MULVIHILL, E. \& HOLLAND, C. The expanded spectrum of toxocaral disease. Lancet, 26: 692- 695, 1988

31. THOMPSON, D.E.; BUNDY, D.A.P.; COOPER, E.S. \& SCHANTZ, P.M. Epidemiological characteristics of Toxocara canis zoonotic infection of children in a Caribbean community. Bull. Wld. Hlth. Org., 64: 283-290, 1986.

32. VAN KNAPEN, F. \& BUIJS, J. - Diagnosis of Toxocara infection. In: LEWIS, J.W. \& MAIZEL, R.M. Toxocara and toxocariasis. Clinical, epidemiological and molecular perspectives. London, British Society for Parasitology, 1993. p. 49-53.

33. VIRGINIA, P.; NAGAKURA, K.; FERREIRA, O. \& TATENO, S. - Serologic evidence of toxocariasis in Northeast Brazil. Jap. J. med. Sci. Biol., 44: 1-6, 1991.

34. WORLD HEALTH ORGANIZATION - Fifth report of the WHO expert committee on filariasis, lymphatic filariasis: the disease and control. Geneva, WHO, 1992.

35. WORLEY, G.; GREEN, J.A.; FROTHINGHAM, T.E. et al. - Toxocara canis infection: clinical and epidemiological associations with seropositivity in kindergarten children. J. infect. Dis., 149: 591-597, 1984.

Received: 1 August 2003

Accepted: 24 March 2004 